\title{
OmniaScience
}

\section{The influence of Service Quality on Satisfaction: Does gender really matter?}

\author{
See Ying Kwok ${ }^{1}$, Ahmad Jusoh², Zainab Khalifah ${ }^{2}$ \\ ${ }^{1}$ Universiti Tunku Abdul Rabman, ${ }^{2}$ Universiti Teknologi Malaysia (Malaysia) \\ s.ying0525@yaboo.com._abmadj@,management.utm.my.zainab@,management.utm.my
}

Received June, 2015

Accepted January, 2016

\section{Abstract}

Purpose: This study examined the influence of service quality on satisfaction and investigated whether satisfaction varies between male and female in response to the perceived service quality in the Malaysian tourism context.

Design/methodology: The population of the study was tourists travelling to Malaysia. A sample was drawn using a multi-stage sampling method and 301 completed questionnaires were analysed with the structural equation modelling.

Findings: The findings showed that service quality was positively associated to satisfaction and the relationship was found to be moderated by gender. Additionally, the findings also showed that service quality perceived by women was found to influence the satisfaction level greater than that of men in the tourism context.

Research limitations/implications: Other demographic variables such as age, culture, education level, and income must also be considered in future study and when developing marketing strategies.

Practical implications: Gender differences are significant moderator between service quality and satisfaction in tourism context. Tourism service providers who target on women's market 
are recommended to allocate more resources and attention on important aspects namely, reliability, considerability and empathy, and tangibility aspects in order to increase the satisfaction level among female tourists.

Originality/value: The findings validated what previous studies found by examining the moderator role of gender in the relationship between service quality and satisfaction in the Malaysian context.

Keywords: Service Quality, Satisfaction, Gender

Jel Codes: M390, C380, C390

\section{Introduction}

The travel and tourism industry in Malaysia is developing continuously, which is parallel with the worldwide tourism industry. In Malaysia, visitor arrivals increased from 13.29 million in 2002 to 25.03 million in 2012 as shown in Table 1 (Tourism Malaysia, n.d.). Tourism revenues also increased from RM25.8 billion to RM60.6 billion in the same period (Tourism Malaysia, n.d.). Due to this, the increment of tourist arrivals proves to lead to a positive increase in the gross revenue of the country. For instance, successful tourism business will provide greater revenues to the host country, especially for countries with abundant tourism resources. For example, in 2012 alone, the tourist receipts contributed $12.5 \%$ of Malaysian Gross Domestic Product and the tourism sector was ranked the second largest of the foreign exchange earners in 2012 (Prime Minister's Department, 2014).

In order to increase and sustain the number of tourists visiting Malaysia, it is essential to ensure that their level of satisfaction is high. This is because having high satisfaction level is the key point for positive word-of-mouth and better retention rate (Hoffman \& Bateson, 2011), which contributes to continuous revenue generation to a country. Therefore, instilling better understanding of related factors that create tourist satisfaction is important. 


\begin{tabular}{|r|r|r|}
\hline Year & Arrivals (million) & \multicolumn{2}{|c|}{ Receipts (billion) } \\
\hline $\mathbf{2 0 1 2}$ & 25.03 & 60.6 \\
\hline $\mathbf{2 0 1 1}$ & 24.71 & 58.3 \\
\hline $\mathbf{2 0 1 0}$ & 24.58 & 56.5 \\
\hline $\mathbf{2 0 0 9}$ & 23.65 & 53.4 \\
\hline $\mathbf{2 0 0 8}$ & 22.05 & 49.6 \\
\hline $\mathbf{2 0 0 7}$ & 20.97 & 46.1 \\
\hline $\mathbf{2 0 0 6}$ & 17.55 & 36.3 \\
\hline $\mathbf{2 0 0 5}$ & 16.43 & 32.0 \\
\hline $\mathbf{2 0 0 4}$ & 15.70 & 29.7 \\
\hline $\mathbf{2 0 0 3}$ & 10.58 & 21.3 \\
\hline $\mathbf{2 0 0 2}$ & 13.29 & 25.8 \\
\hline
\end{tabular}

Source: (Tourism Malaysia, n.d.)

Table 1. Tourist Arrivals and Receipts to Malaysia for the Year 2002 to 2012

In a competitive business environment, the survival of an organization depends on the extent of customers' needs and whether or not their requirements are met. When customer requirements are met, a positive disconfirmation exists, which results in customer satisfaction, positive word-of-mouth, and retention. A satisfied customer often purchases more items and on a regular basis, and will lead to loyalty in the long run (Hoffman \& Bateson, 2011). In addition, the efforts and initiatives to improve customer satisfaction are crucial because dissatisfied customers are more likely to share their bad experiences with others than satisfied customers do (Hoffman \& Bateson, 2011; Hoyer \& Maclnnis, $2007,2010)$. If customer satisfaction is the highest priority of a total quality organization, then the focus on the factors that contribute to overall customer satisfaction is critical. Furthermore, studies related to the issue of customer satisfaction are sensible due to the dynamic nature of the business environment and customer preferences.

For that reason, numerous studies on satisfaction have been carried out across industries, where tourism industry is not an exception (e.g. banking (Mosahab, Mahamad \& Ramayah, 2010; Tan, Suki \& Suki, 2012); transportation (Lai \& Chen, 2010); retail (Im \& Ha, 2011); education (Mansori, Zarina \& Ismail, 2014; Tuan, 2012); mobile broadband (Jusoh, Zakuana, Baharia, Ariffa \& Hayata, 2012); airline (Namukasa, 2013); health care (Faria \& Mendes, 2013); tourism (Aziz, Ariffin, Omar \& Yoon, 2011; Chen \& Chen, 2010; Yoon, Lee \& Lee, 2009) and many more). Service quality is generally dominated as the significant explanatory factor to satisfaction (González, Comesaña \& Brea, 2007; Ekinci, Dawes \& Massey, 2008; Meng \& Elliott, 2009; Rojas \& Camarero, 2009). The current literature dealing with the interaction of gender to service quality and satisfaction is, however, still lacking (Mokhlis, 2012) even with a few exceptions. For instance, the moderator role of gender on perceived quality has been 
discussed and empirically proven in the context of hotel industry (Juwaheer, 2011), public services (Mokhlis, 2012), and banking sector (Karatepe, 2011).

Even though some researches have investigated the effects of gender differences between service quality and satisfaction relationships, the study on gender role remains infrequent. It is worth to note that gender roles may be significant during evaluation stage (Hoyer \& MacInnis, 2010) and thus, seem able to describe more on satisfaction level, particularly in response to the assessment of perceived service quality. For instance, Im and Ha (2011) called for further studies on gender differences because their post hoc analysis pointed out significant gender differences in several aspects, such as perceived variety, disconfirmation, as well as satisfaction. Therefore, extra attention is necessary in order to provide sufficient credentials for the moderating role of gender in distinguishing the strength of association between service quality and satisfaction.

Furthermore, improving the understanding on gender differences is a beneficial marketing strategy. Several studies have noted that gender is a genuine variable sufficiently strong to be counted as a driver of market segmentation and successful marketing strategy, because gender is easy to identify and access, and substantial to be profitable (Juwaheer, 2011; Mokhlis, 2012; Ryan, Henley \& Soutar, 1998). Besides that, Juwaheer (2011) also claimed that gender differences also represent a 'differential potential' deemed to be sufficient to justify whether a destination specifically draws attention to qualities that separately appealing to male and female visitors (Ryan et al., 1998). For marketing purposes, gender differences may be noteworthy to be considered as separate subcultures (Peter \& Olson, 2010). For that reason, this study attempts to extend the previous studies by examining the moderating effect of the tourist genders in the Malaysian tourism context.

\section{Literature review}

\subsection{Satisfaction}

Oliver (1980) defined satisfaction as the perceived difference between expectation and perceived performance. For instance, Woodside, Frey and Daly (1989) suggested that satisfaction is related to how much a person likes or dislikes a product or service after consuming it, or a response to the perceived difference between expectation and perceived performance (Oliver, 1981; Tze \& Wilton, 1988). 
The comparison between expectation and performance is based on the Expectancy Disconfirmation Model (Hoffman \& Bateson, 2006, 2011). When the actual performance meets the expectation, the expectation is confirmed and the consumer is satisfied. However, if the perceived performance is lower or higher than the expectation, a negative or positive disconfirmation is created. For instance, when a perceived performance is higher than the expectation, it tends to lead to positive disconfirmation and a satisfied customer. On the other hand, when a negative disconfirmation is created, the customer tends to be dissatisfied because the perceived performance is lower than expectation. In short, the satisfaction in this study refers to the tourists' feeling, in terms of their liking and disliking their visit to Malaysia based on their comparison of expectation to the actual trip experience.

\subsection{Service Quality and Satisfaction}

Service quality is the conformance of customer requirements to the service delivered (Chakrabarty, Whitten \& Green, 2007). Generally, it is widely accepted that service quality depends on the degree of actual service performance in meeting customer's need and expectation (Asher, 1996; Grönroos, 1990; Presbury, Fitzgerald \& Chapman, 2005). In this study, service quality is interpreted as tourists' judgment on the perceived services during their visit to Malaysia.

According to the perspective of Parasuraman, Zeithaml and Berry (1985), satisfaction level is influenced by the gap between service perception and expectation. For instance, a better fit between service perceptions with service performance will reduce the gap leading to a higher quality service and consequently higher satisfaction (Asher, 1996; Ekinci, 2004; Parasuraman et al., 1985; Parasuraman, Zeithaml \& Berry, 1994). The disconfirmation theory supports the gap view, meaning that when perceptions meet or exceed quality expectation, positive disconfirmation is formed and the customer is satisfied. Otherwise, the customer is dissatisfied suggesting a negative disconfirmation when perceived quality is lower than expectation.

Positive relationships between service quality and satisfaction are supported by previous researchers (Al-Ababneh, 2013; Ekinci et al., 2008; González et al., 2007; Meng \& Elliott, 2009; Rojas \& Camarero, 2009; Tuan, 2012). Therefore, it is rational to accept as true that a higher service quality will increase the level of satisfaction among the tourists, and the hypothesis is formulated as follows:

H1: Service Quality has positive effects on Satisfaction. 


\subsection{Gender difference}

Demographic variables, such as age, gender, education and socioeconomic status are known as customer characteristics. To a certain extent, these characteristics are significant determinants of consumer behaviours. Among these characteristics, gender appears to be one of the few features that are easy to recognize and access, and is a large enough segment to be profitable for market strategy (Juwaheer, 2011; Mokhlis, 2012). Therefore, this study seeks to exploit gender differences to determine the level of satisfaction in response to service quality.

Gender refers to a set of characteristics differentiating males from females. Other than being physically or biologically different, males and females can be different in traits, attitudes, and activities that are able to influence consumer behaviour (Hoyer \& Maclnnis, 2010). Each gender observes the environment; processes, evaluates and retrieves information, and makes judgments in different ways (Hoyer \& Maclnnis, 2010; Karatepe, 2011).

For instance, women pay attention to both personally relevant information and information relevant to others (Hoyer \& Maclnnis, 2010) and tend to be more likely to engage in a detailed, in-depth examination of a message and make extended decision based on product attributes (Hoyer \& Maclnnis, 2010; Karatepe, 2011). Men, however, only focus on personally related information (Hoyer \& Maclnnis, 2010) and tend to use simple heuristics and process information based on few details (Hoyer \& Maclnnis, 2010; Karatepe, 2011). Accordingly, it can be argued that women place more emphasis on quality because they consider and evaluate in detail every single aspect of the products and/or services they acquired, while male customers evaluate the overall aspects.

Therefore, it is not surprising that the expectation of the service or products for females is likely to be higher than male customers together with lower perceptions score report than male customers do (Juwaheer, 2011), which, in turn, affects the level of the satisfaction. Sánchez-Hernández, Martínez-Tur, Peiró and Moliner (2010) indicated that women and men differ in the association of functional and relational dimensions of service quality with their satisfaction and loyalty based on their study in Mexican hotels. Functional service quality was higher for male guests, while relational service quality showed greater predictive power for female guests.

On the other hand, the study conducted by the public service organization indicated that male respondents rated perceived service quality better in comparison to female respondents (Mokhlis, 2012). Five SERVQUAL dimensions collectively explained $48.1 \%$ of the variance of male customers' satisfaction and $53.8 \%$ for difference of the female customers' satisfaction. In addition, the findings of 
Karatepe's (2011) study also proved the moderating role of gender in the relationship between service quality and customer satisfaction in banking context.

For that reason, the association between service quality and satisfaction seems to vary between male and female customers. Considering the importance of gender role in fine-tuning the strength of the relationship of service quality and satisfaction, the second hypothesis, therefore, is formulated as follows:

H2: Gender moderates the relationship between service quality and satisfaction.

\section{Methodology}

The population of the study is made up of tourist groups that travelled to Malaysia. The population was large and hence, a sample was chosen to represent the population. In addition, a set of questionnaire was used as the instrument for data collection. Service quality was measured with five dimensions adapted from SERVQUAL (22 items), while Satisfaction was measured with five items. Both service quality and satisfaction were measured with 5-point Likert scale. Also, the demographic background of the respondents was assessed.

In this study, the multi-stage sampling method comprises stratified and convenience sampling techniques was used to draw the samples. Firstly, the stratified sampling technique was undertaken. The sample was divided into two groups, namely ASEAN tourists and non-ASEAN tourists. Secondly, the convenience sampling technique was used to draw the sample at selected locations. The used of convenience sampling method is not something new or uncommon in the context of tourism study and has been utilised by researchers (e.g. Jamal, Othman \& Muhammad, 2011; Wu \& Li, 2014; Ali, 2015; Jani, Jang \& Hwang, 2014) in their study of the tourism context. According to Jamal et al. (2011), convenience sampling is the most appropriate sampling technique for the study with unidentified population and sampling frame. Subsequently, the non-probability sampling method was employed due to no accurate tourist sampling frame, limited time and cost, and high mobility of the respondents (international tourists).

Four tourist destinations, namely Penang, Sabah, Kuala Lumpur and Malacca, which are among the top five destinations in Malaysia frequently visited by international tourists were selected for the field work. During the survey period, the questionnaires were distributed to willing respondents after a few screening questions to ensure they qualified as respondents. Also, the respondents were requested to 
answer and return the questionnaires on the spot. After removing three incomplete questionnaires, 301 completed questionnaires were used for data analysis, resulting in 75 percent of usable rate for analysis. Returned questionnaires were analysed with both SPSS and AMOS software and reported in the following section.

\section{Data analysis}

\subsection{Profile}

The background profile (Table 2) was briefly reviewed to provide a basic concept of the respondents engaged in the survey. In this study, a total of 198 respondents were from non-ASEAN countries and 103 respondents from ASEAN countries. Besides that, 56.8\% of the respondents were female $(\mathrm{n}=171)$, and $43.2 \%$ were male $(n=130)$. The results also indicated that $47.8 \%$ or 144 respondents were married. Other than that, the tourists aged 40 and below made up the majority of the tourist groups. Based on the statistical results, most of the tourists visited Malaysia for vacation purposes, which consisted of 238 out of 301 respondents ( $79.1 \%$ of the respondents).Moreover, the statistical results showed that the tourists preferred to travel on their own (86.4\%) rather than using a tour package $(13.6 \%)$.

\begin{tabular}{|c|c|c|c|}
\hline \multicolumn{2}{|r|}{ Items } & Frequency & Percent, \% \\
\hline \multirow[t]{2}{*}{ Nationality } & ASEAN & 103 & 34.2 \\
\hline & Non-ASEAN & 198 & 65.8 \\
\hline \multirow{2}{*}{ Gender } & Male & 130 & 43.2 \\
\hline & Female & 171 & 56.8 \\
\hline \multirow{5}{*}{ Age } & 30 and below & 137 & 45.5 \\
\hline & $31-40$ & 107 & 35.5 \\
\hline & $41-50$ & 36 & 12.0 \\
\hline & $51-60$ & 12 & 4.0 \\
\hline & 61 and above & 9 & 3.0 \\
\hline \multirow{3}{*}{ Marital Status } & Single & 119 & 39.5 \\
\hline & Married & 144 & 47.8 \\
\hline & Others & 38 & 12.6 \\
\hline \multirow{6}{*}{$\begin{array}{l}\text { Major Purpose of } \\
\text { Visit }\end{array}$} & Holiday & 238 & 79.1 \\
\hline & Business & 11 & 3.7 \\
\hline & Official Mission & 11 & 3.7 \\
\hline & Visiting Friends and Relatives & 22 & 7.3 \\
\hline & Conference & 2 & 0.7 \\
\hline & Others & 17 & 5.6 \\
\hline \multirow{2}{*}{ Mode of Visit } & Tour Package & 41 & 13.6 \\
\hline & Self-guided Tour & 260 & 86.4 \\
\hline
\end{tabular}

Table 2. Profile of the Respondents 


\subsection{The measurement model}

Using the Principal Component analysis with Variamax rotation, the Exploratory Factor Analysis was conducted. 22 service quality items were successfully extracted into four components (factor loading $\geq 0.4$ ) with initial eigenvalues above 1.0, KMO $>0.7$, Bartlett's test value of $\mathrm{p}<0.001$, and explained a total of $64.08 \%$ variance $(>60 \%)$. On the other hand, for satisfaction, all of the five satisfaction items were extracted into a single component with initial eigenvalues $>1.0$ (total variance explained $=68.62 \%), \mathrm{KMO}=0.825$ and Bartlett's test value $<0.001$. Afterward, CFA analysis was conducted based on the EFA results using AMOS software.

After deletion of the poorly load items $(<0.6)$, the CFA model provided a good fit to the sample data $\left(\chi^{2}=233.734\right.$, df $\left.12, \chi^{2} / \mathrm{df}=1.885\right)$. The GFI was .923, AGFI $=.893, \mathrm{CFI}=.965$, TLI $=.957$ and RMSEA $=.054$. In order to ensure the validity and reliability, several tests were conducted. The composite reliability values exceeded 0.7 (Table 3) and the AVE value of all the latent factors were ranged from 0.593 to 0.7 (AVE >0.5), which indicated that both reliability and convergent validity were achieved. Similarly, the discriminant validity was supported with the square root AVE values, which were greater than the intercorrelation coefficients among the constructs, as shown in Table 4.

\begin{tabular}{|c|c|c|c|c|}
\hline & Items & FL & CR & AVE \\
\hline & Reliability & & 0.879 & 0.593 \\
\hline C11 & Generally, the service providers had performed the right services at the first time & 0.8 & & \\
\hline C9 & Generally, the service providers had performed services as promised & 0.82 & & \\
\hline C10 & Generally, the service providers had served as the time promised & 0.81 & & \\
\hline C8 & Generally, the service providers had kept me informedabout when services will be performed & 0.7 & & \\
\hline \multirow[t]{2}{*}{ C7 } & Generally, the service providers had informed on services delivered & 0.71 & & \\
\hline & Considerability & & 0.864 & 0.613 \\
\hline C12 & Generally, the service providers were caring & 0.79 & & \\
\hline C15 & Generally, the service providers were courteous/polite & 0.74 & & \\
\hline C13 & Generally, the service providers were helpful & 0.83 & & \\
\hline \multirow[t]{2}{*}{ C14 } & Generally, the service providers were trustworthy & 0.77 & & \\
\hline & Empathy & & 0.837 & 0.633 \\
\hline C17 & Generally, the service providers were able to understand my needs & 0.71 & & \\
\hline $\mathrm{C} 20$ & Generally, the service providers were able to provide individual attention & 0.84 & & \\
\hline \multirow[t]{2}{*}{ C19 } & Generally, the service providers had my best interest at heart & 0.83 & & \\
\hline & Tangibility & & 0.823 & 0.7 \\
\hline C1 & Generally, the service providers had modern equipment & 0.78 & & \\
\hline \multirow[t]{2}{*}{$\mathrm{C} 2$} & Generally, the service providers had attractive facilities & 0.89 & & \\
\hline & Satisfaction & & 0.892 & 0.675 \\
\hline S1 & My choice of having this trip is a __ one "very bad" to "very good" & 0.79 & & \\
\hline S2 & My feeling towards this trip can be best described as___ "very dissatisfied" to "very satisfied" & 0.86 & & \\
\hline S3 & I am satisfied with my decision of having this trip "strongly disagree" to "strongly agree" & 0.88 & & \\
\hline S4 & I will recommend this trip to others in the future "strongly disagree" to "strongly agree & 0.75 & & \\
\hline
\end{tabular}

Table 3. Convergent Validity and Composite Reliability 


\begin{tabular}{|l|r|r|r|r|r|}
\cline { 2 - 6 } \multicolumn{1}{c|}{} & Empathy & Reliability & Satisfaction & Considerability & Tangibility \\
\hline Empathy & $\mathbf{0 . 7 9 6}$ & & & & \\
\hline Reliability & 0.670 & $\mathbf{0 . 7 7 0}$ & & & \\
\hline Satisfaction & 0.460 & 0.260 & $\mathbf{0 . 8 2 2}$ & & \\
\hline Considerability & 0.680 & 0.540 & 0.290 & $\mathbf{0 . 7 8 3}$ & \\
\hline Tangibility & 0.410 & 0.470 & 0.190 & 0.430 & $\mathbf{0 . 8 3 7}$ \\
\hline
\end{tabular}

The Bold values are the square root of AVE

Table 4. Discriminant Validity

\subsection{Relationship between Service Quality and Satisfaction}

The relationship between Service Quality and Satisfaction was examined using a structural model. Service Quality (a second-order factor with four first-order factors) was regressed to Satisfaction (a first-order factor). The goodness-of-fit indices showed that this model fitted the data adequately. The chi-square/df was $1.881\left(\chi^{2}=240.811, \mathrm{df}=128\right)$. The GFI was .919, AGFI=.892, CFI=.964, TLI=.957 and RSMEA $=.054$. The model that fitted the criteria for the path model was satisfactory, thus the model was accepted to fit the data. A positive and significant relationship $(\beta=0.44, \mathrm{p}<0.01)$ was found between Service Quality and Satisfaction, and thus, H1 was supported. 20\% of the variance in Satisfaction can be explained by the Service Quality (Table 5).

\begin{tabular}{|l|r|c|c|}
\hline \multicolumn{1}{|c|}{ Link in the model } & Standardised Estimate (r) & rc $^{2}$ & CR \\
\hline Service Quality $->$ Satisfaction & $0.44^{* *}$ & 0.20 & 6.01 \\
\hline Note: ${ }^{* *} \mathrm{p}<0.01$ (one-tailed test)
\end{tabular}

Table 5. Result of hypothesis testing (H1)

\subsection{Gender as a moderator}

The guidelines provided by Hair, Black, Babin and Anderson (2010) were used to test the moderator. First, two models namely model 1 (constraint) and model 2 (unconstraint) were developed. In model 1, constraint was put to fix the relationship between constructs of interest to be equal to 1 . In model 2 , the relationship coefficient was allowed to be freely estimated. Based on this model, analysis was performed on both male and female groups (Hair et al., 2010). As such, the data were divided into Male and Female categories, with 130 respondents in Male category and 171 respondents in Female category. 
First, the model was tested using Male data (n=130), adding a constraint fixing " 1 " in the relationship between Service Quality and Satisfaction (Hair et al., 2010). Later, using the same model, the parameter constraint in the path was removed. A difference in chi-squared $\left(\Delta \chi^{2}\right)$ values between the two models (constraint and unconstraint) was used to identify the moderating effect on the relationship between Service Quality and Satisfaction (Hair et al., 2010). The difference in chi-squared $\left(\Delta \chi^{2}\right)$ value was 4.20. The result showed that the moderation effect was significant at $\mathrm{df}=1$ for Male group as shown in Table 6. Next, the same test procedure was conducted for Female group $(n=171)$. The constraint (equal to " 1 ") and unconstraint models for Female were developed. The difference in chi-squared $\left(\Delta \chi^{2}\right)$ value was 5.651, $\mathrm{df}=1$. This indicated that the moderation effect was significant for Female as well, as shown in Table 6.

The results showed that the model without constraints was significantly better (with smaller $\chi^{2}$ ) than the constrained model, indicating that the two groups' coefficients were significantly different. From the significant difference in the chi-squared $\left(\Delta \chi^{2}\right)$ values between the two models, it can be concluded that constraining the parameters to be equal between groups produced a poorer fit. Therefore, it can be concluded that Gender moderated the relationship between Service Quality and Satisfaction, which means H2 was supported. This means that the influence of Service Quality on Satisfaction creation differs between Male and Female tourists. Additionally, the effect of Female ( $\mathrm{rc}=0.46)$ was more noticeable compared to Male group ( $\mathrm{rc}=0.38$ ). This means that more variance of satisfaction level is exhibited by service quality for women than men.

\begin{tabular}{|c|c|c|c|c|}
\hline \multirow{2}{*}{$\begin{array}{l}\text { Group } \\
\text { Model } \\
\end{array}$} & \multicolumn{2}{|c|}{ Male, $n=130$} & \multicolumn{2}{|c|}{ Female, $n=171$} \\
\hline & Constraint & Unconstraint & Constraint & Unconstraint \\
\hline$\chi^{2}$ & 160.008 & 155.808 & 255.487 & 249.836 \\
\hline df & 129 & 128 & 129 & 128 \\
\hline$\chi^{2} / \mathrm{df}$ & 1.240 & 1.217 & 1.981 & 1.952 \\
\hline GFI & .881 & .886 & .860 & .863 \\
\hline AGFI & .843 & .847 & .815 & .817 \\
\hline CFI & .972 & .975 & .940 & .942 \\
\hline TLI & .966 & .970 & .929 & .931 \\
\hline RMSEA & .043 & .041 & .076 & .075 \\
\hline$\Delta \chi^{2}$ & 4.20 & & 5.651 & \\
\hline$\Delta \mathrm{df}$ & 1 & & 1 & \\
\hline $\mathrm{rc}^{2}$ & .14 & & .21 & \\
\hline $\mathrm{rc}$ & $.38^{* *}$ & & $.46^{* *}$ & \\
\hline CR & 3.32 & & 4.74 & \\
\hline
\end{tabular}

Table 6. The Moderation Test Results (H2) 


\section{Discussion and implications}

The relationship between service quality and satisfaction is well discussed in the literature (e.g. Meng \& Elliott, 2009; Rojas \& Camarero, 2009; Tuan, 2012) accordingly and the positive relationship was supported. The SEM analysis conducted in this paper provides similar results where service quality was significantly and positively regressed to satisfaction in the tourism context. Therefore, it is supported that the increment of service quality perceived will increase the level of satisfaction among international tourists. Hence, H1 was supported.

Previously, the moderator role of gender in the relationship between service quality and satisfaction has been discussed and empirically proven in different contexts, such as the hotel industry, public services and banking (Juwaheer, 2011; Karatepe, 2011; Mokhlis, 2012). Similarly to the findings in past researches, this study statistically proved the moderator role of gender in the relationship between service quality and satisfaction among tourists in the Malaysian context by utilising the multi-group analysis. This entails that the extent of the difference in satisfaction in response to the service quality perceived between male and female tourists was not equal. Thus, H2 was supported.

In addition, the findings also showed that the quality of services perceived by female tourists was found to manipulate the satisfaction level greater than that of male tourists. The findings were consistent with the researcher's expectation, where women appeared to emphasize on quality aspects. Women tend to gather loads of information (Hoyer \& Maclnnis, 2010) and are more likely to evaluate after engaging in detailed and comprehensive examination of a message (Hoyer \& Maclnnis, 2010; Karatepe, 2011). Therefore, women's prior consumption expectation will be higher and they look into every tiny aspect or attribute of the services received, consequently, the greater extent of the women satisfaction level is determined by the quality of their perceived services, which is in contrast to men.

The study investigated the moderating role of gender in the relationship between service quality and satisfaction. Using the SEM analysis, satisfaction was found to be varied among male and female tourists in response to service quality. The findings in this study have validated the moderator effect of gender in the service quality-satisfaction relationship in the Malaysian tourism context.

Furthermore, the findings in this study are beneficial from the practitioners' perspective as well. The findings indicated that female tourists are more aware of the quality of services in comparison to male tourists. Female travellers are growing in number (Juwaheer, 2011), which is changing the market. Tourism marketers should therefore reconsider current service strategies and introduce the newer ones to suit the market. 
Due to scarce resources that used to be an issue in resource allocation, tourism service practitioners should decide which aspects to change or improve. For that reason, the findings were further reviewed to find out the dimensions that cause the difference between the service quality perceived among men and women in this study. When some dimensions are equally important, the tangible aspects, however, do not appear to be the same from the men's and women's perspective in this study. The tangible part was more important to differentiate the level of perceived quality for women $(\mathrm{rc}=0.64, \mathrm{CR}=4.6)$ than men $(\mathrm{rc}=0.25, \mathrm{CR}=1.98)$, which in turn, affects the variance on satisfaction level. This means that women seem more focused on the tangibles cues in comparison to men. Therefore, for tourism service providers who mainly target on men's market, they are advised to emphasize and allocate more resources and attention on relatively important aspects to men, such as reliability, considerability and empathy before they attempt to improve the tangible aspects. However, for tourism practitioners whose seek to increase the satisfaction as a whole regardless of gender differences, they have to work out all service dimensions: reliability, considerability, empathy and also the tangible aspects, because all of these four factors were found to significantly contribute to the perceived service quality, which has an impact on satisfaction for both groups.

Moreover, based on the EFA and CFA results, two items adopted from SERVQUAL have been successfully loaded into tangibility dimension, which are modern equipment and attractive facilities. This result gives the tourism service providers a clear direction that the female tourists tend to look for modern equipment and attractive facilities during their travel. Therefore, these two features will be of important to be considered if the service providers intend to increase the customer satisfaction level (tourist satisfaction level in this study) through improving the customer perceived quality, especially for the market of female travellers that are growing.

\section{Limitations and suggestions}

The study successfully verified the positive relationship between service quality and satisfaction, as well as the role of gender as a moderator. Nevertheless, the interpretation of the result must be done carefully. According to the statistical result, service quality explains about $15-20 \%$ of the variance of satisfaction for male and female tourists (Table 6) in this study. This means that service quality only manages to explain a small portion of the variance of tourist satisfaction, which signals that there might be explanatory factors that have not been taken into consideration in this study. Therefore, in the future, other possible factors could be included to enrich the understanding on tourist satisfaction. 
In addition, even though gender is an important aspect to be considered during the stage of marketing strategy development, it is not the only characteristic on which the marketing efforts should be based. Due to that reason, the inclusion of only one demographic factor that is gender is considered as a limitation of the study. Other demographic variables, such as age, culture, education level, and income must also be considered in future study and when developing marketing strategies.

Besides that, this study only focused on the Malaysian tourism industry. Each industry has its own specific characteristics, and hence, the outcomes of the study may vary and not be applicable for other industries or other countries. For instance, female tourists were found to emphasise more on the tangible aspects than male tourists do in this study. This finding however, contrasts with Mokhlis' (2012) findings in which male respondents featured greater importance on tangible factors than females in his study of the public service sector. Therefore, the researcher calls for more studies, especially in tourism industry in other countries to validate the findings of the present research.

\section{Acknowledgments}

The work is financed by Fundamental Research Grant Scheme (FRGS), Kementerian Pendidikan, Malaysia under Vote R.J130000.7829.4F666.

\section{References}

Al-Ababneh, M. (2013). Service Quality and its Impact on Tourist Satisfaction. Interdisciplinary Journal of Contemporary Research In Business, 4(12), 164-177.

Ali, F. (2015). Heritage Tourist Experience, Nostalgia, and Behavioural Intentions. Anatolia: An International Journal of Tourism and Hospitality Research, 26(3), 472-475. http://dx.doi.org/10.1080/13032917.2015.1013477

Asher, M. (1996). Managing Quality in The Service Sector. London: Kogan Page.

Aziz, N.A., Ariffin, A.A.M., Omar, N.A., \& Yoon, S.K. (2011). An Investigation of International and Domestic Tourists' Satisfaction in Heritage Context: Implications for Destination Marketing. Journal Pengurusan, 33, 61-76. 
Chakrabarty, S., Whitten, D., \& Green, K. (2007). Understanding service quality and relationship quality in IS outsourcing: Client orientation \& promotion, project management effectiveness, and the tasktechnology-structure fit. Journal of Computer Information Systems, 48(2), 1-15.

Chen, C.-F., \& Chen, F.-S. (2010). Experience Quality, Perceived Value, Satisfaction and Behavioral Intentions for Heritage Tourists. Tourism Management, 31(2010), 29-35. http://dx.doi.org/10.1016/j.tourman.2009.02.008

Ekinci, Y. (2004). An Investigation of the Determinants of Customer Satisfaction. Tour Anal, 8, 197-203.

Ekinci, Y., Dawes, P.L., \& Massey, G.R. (2008). An Extended Model of the Antecedents and Consequences of Consumer Satisfaction for Hospitality Services. European Journal of Marketing, 42(1/2), 35-68. http://dx.doi.org/10.1108/03090560810840907

Faria, N., \& Mendes, L. (2013). Organizational Image's Partial Mediation Role between Quality and Users' Satisfaction. The Service Industries Journal, 33(13-14), 1275-1293. http://dx.doi.org/10.1080/02642069.2013.815733

González, M.E.A., Comesaña, L.R., \& Brea, J.A.F. (2007). Assessing Tourist Behavioral Intentions through Perceived Service Quality and Customer Satisfaction. Journal of Business Research, 60(2), 153-160. http://dx.doi.org/10.1016/j.jbusres.2006.10.014

Grönroos, C. (1990). Relationship Approach to Marketing in Service Contexts: The Marketing and Organizational Behaviour Interface. Journal of Business Research, 20(1), 3-11. http://dx.doi.org/10.1016/0148-2963(90)90037-E

Hair, J.F., Black, W.C. J., Babin, B.J., \& Anderson, R.E. (2010). Multivariate Data Analysis (7th ed.). New Jersey: Pearson Prentice Hall.

Hoffman, K.D., \& Bateson, J.E.G. (2006). Services Marketing: Concepts, Strategies, and Cases (3 ed.). USA: Thompson South-Western.

Hoffman, K.D., \& Bateson, J.E.G. (2011). Services Marketing: Concepts, Strategies, and Cases (4th ed.). USA: South-Western Cengage Learning.

Hoyer, W.D., \& Maclnnis, D.J. (2007). Consumer Behavior (4th ed.). Boston, MA: Houghton Mifflin.

Hoyer, W.D., \& Maclnnis, D.J. (2010). Consumer Behavior (5th ed.). USA: South-Western, Cengage Learning. 
Im, H., \& Ha, S. (2011). An Exploration of the Cognitive-Affective Model of Satisfaction in a Shopping Context: A Test of Competing Models. The Service Industries Journal, 31(13), 2273-2288. http://dx.doi.org/10.1080/02642069.2010.504983

Jamal, S.A., Othman, N.A., \& Muhammad, N.M.N. (2011). The Moderating Influence of Psychographics in Homestay Tourism in Malaysia. Journal of Travel \& Tourism Marketing, 28(1), 48-61. http://dx.doi.org/10.1080/10548408.2011.535443

Jani, D., Jang, J.-H., \& Hwang, Y.-H. (2014). Big Five Factors of Personality and Tourists' Internet Search Behavior. Asia Pacific Journal of Tourism Research, 19(5), 600-615. http://dx.doi.org/10.1080/10941665.2013.773922

Jusoh, A., Zakuana, N., Baharia, A.Z., Ariffa, M.S.M., \& Hayata, M. (2012). Determining the Effects of Mobile Broadband Counter Service as Moderator Variable to the Relationship between Service Quality and Customer Satisfaction. Elsevier Procedia - Social and Behavioral Sciences, 40(2012), 264-268.

Juwaheer, T.D. (2011). Gender Bias in Hotel Guests' Perceptions of Service Quality: An Empirical Investigation of Hotels in Mauritius. E-Review of Tourism Research, 9(5), 164-189.

Karatepe, O.M. (2011). Service Quality, Customer Satisfaction and Loyalty: The Moderating Role of Gender. Journal of Business Economics and Management, 12(2), 278-300.

http://dx.doi.org/10.3846/16111699.2011.573308

Lai, W.-T., \& Chen, C.-F. (2010). Behavioral Intentions of Public Transit Passengers -The Roles of Service Quality, Perceived Value, Satisfaction and Involvement. Transport Policy, 18(2011), 318-325. http://dx.doi.org/10.1016/j.tranpol.2010.09.003

Mansori, S., Zarina, A.V., \& Ismail, M.M. (2014). Service Quality, Satisfaction and Student Loyalty in Malaysian Private Education. Asian Social Science, 10(7), 57-66. http://dx.doi.org/10.5539/ass.v10n7p57

Meng, J., \& Elliott, K.M. (2009). Investigating Structural Relationship between Service Quality, Switching Costs, and Customer Satisfaction. The Journal of Applied Business and Economics, 9(2), 54-66.

Mokhlis, S. (2012). The Influence of Service Quality on Satisfaction: A Gender Comparison. Public Administration Research, 1(1), 103-112. http://dx.doi.org/10.5539/par.v1n1p103

Mosahab, R., Mahamad, O., \& Ramayah., T. (2010). Service Quality, Customer Satisfaction and Loyalty: A Test of Mediation. International Business Research, 3(4), 72-80. http://dx.doi.org/10.5539/ibr.v3n4p72

Namukasa, J. (2013). The Influence of Airline Service Quality on Passenger Satisfaction and Loyalty. The TQM Journal, 25(5), 520-532. http://dx.doi.org/10.1108/TQM-11-2012-0092 
Oliver, R.L. (1980). A Cognitive Model of the Antecedents and Consequences of Satisfaction Decisions. Journal of Marketing Research, 17(November), 460-469. http://dx.doi.org/10.2307/3150499

Oliver, R.L. (1981). Measurement and Evaluation of Satisfaction Processes in Retail Setting. Journal of Retailing, 57(Fall), 25-48.

Parasuraman, A., Zeithaml, V.A., \& Berry, L.L. (1985). A Conceptual Model of Service Quality and its Implications for Future Research. Journal of Marketing, 49(Fall), 41-50. http://dx.doi.org/10.2307/1251430

Parasuraman, A., Zeithaml, V.A., \& Berry, L.L. (1994). Alternative Scales for Measuring Service Quality: A Comparative Assessment based on Psychometric and Diagnostic Criteria. Journal of Retailing, 70(3), 201-230. http://dx.doi.org/10.1016/0022-4359(94)90033-7

Peter, J.P., \& Olson, J.C. (2010). Consumer Behaviour and Marketing Strategy (9th ed.). New York: McGrawHill Irwin.

Presbury, R., Fitzgerald, A., \& Chapman, R. (2005). Impediments to Improvements in Service Quality in Luxury Hotels. Managing Service Quality, 15(4), 357-373. http://dx.doi.org/10.1108/09604520510606835

Prime Minister's Department. (2014). Economic Transformation Programme Annual Report 2013. Malaysia: Performance Management and Delivery Unit.

Rojas, C.d., \& Camarero, C. (2009). Visitors' Experience, Mood and Satisfaction in a Heritage Context: Evidence from an Interpretation Center. Tourism Management, 29(2008), 525-537.

Ryan, M., Henley, N., \& Soutar, G. (1998). Gender Differences in Tourism Destination Choice: Implications for Tourism Marketers. Paper presented at the Australian and New Zealand Marketing Conference, Dunedin, New Zealand.

Sánchez-Hernández, R.M., Martínez-Tur, V., Peiró, J.M., \& Moliner, C. (2010). Linking Functional and Relational Service Quality to Customer Satisfaction and Loyalty: Differences between Men and Women. Psychological Reports, 106(2), 598-610. http://dx.doi.org/10.2466/pr0.106.2.598-610

Tan, C.Y.P., Suki, N.M., \& Suki, N.M. (2012). Service Quality Dimension Effects on Customer Satisfaction towards E-Banking. Interdisciplinary Journal of Contemporary Research In Business, 4(4), $741-751$.

Tourism Malaysia. (n.d.). Tourists Arrivals and Receipts to Malaysia. Retrieved 17 August, 2014, from http://corporate.tourism.gov.my/research.asp?page=facts figures

Tuan, N.M. (2012). Effects of Service Quality and Price Fairness on Student Satisfaction. International Journal of Business and Social Science, 3(19), 132-150. 
Tze, D.K., \& Wilton, P.C. (1988). Model of Consumer Satisfaction Formation: An Extension. Journal of Marketing Research, 25(2), 204-212. http://dx.doi.org/10.2307/3172652

Woodside, A.G., Frey, L.L., \& Daly, R.T. (1989). Linking Service Quality, Customer Satisfaction, and Behavioral Intention. Journal of Health Care Marketing, 9(4), 5-17.

Wu, H.-C., \& Li, T. (2014). A Study of Experiential Quality, Perceived Value, Heritage Image, Experiential Satisfaction, and Behavioral Intentions for Heritage Tourists. Journal of Hospitality \& Tourism Research, March 5, 1-41. http://dx.doi.org/10.1177/1096348014525638

Yoon, Y.-S., Lee, J.-S., \& Lee, C.-K. (2009). Measuring Festival Quality and Value Affecting Visitors' Satisfaction and Loyalty Using a Structural Approach. International Journal of Hospitality Management, 29(2010), 335-342.

Intangible Capital, 2016 (www.intangiblecapital.org) 